\title{
Islam Onlines
}

\section{ekteskapsveiledning}

FøR OG ETTER KRISEN

Hvordan driver et islamsk nettsted ekteskapsveiledning? Består veiledningen kun av referanser til hellige skrifter? Hva slags spørsmål stiller brukerne, og hva slags svar mottar de? Disse spørsmålene utforskes med utgangspunkt i Islam Onlines ekteskapsveiledningstjenester, og kan by på overraskelser. 
TEKST: Mona Abdel-Fadil

ISLAM ONLINE (IOL) har vært en av de meste suksessrike og stabile islamske nettsidene siden den ble opprettet i i 997. ${ }^{\text {I I }}$ 2007 ble IOL regnet som den mest populære religiøse nettsiden på verdensbasis, og blant de hundre meste populære nettsidene på arabisk. ${ }^{2}$ IOL var altså et mainstreamprodukt, og hadde bred appell blant den yngre utdannede generasjonen i blant annet Egypt og Saudi-Arabia. ${ }^{3}$ IOLs popularitet blant brukere skyldtes trolig den betydelige variasjon i tjenester den tilbød, som digitaliserte versjoner av hellige skrifter, egenproduserte nyheter, helsesider og interaktive fatwa $a^{4}$ og veiledningstjenester. Fra begynnelsen (I997) var portalens produksjonskontor i Kairo i Egypt, mens IOL-styret holdt til i Doha i Qatar. IOL hadde sterke ideologiske bånd til Yusuf alQaradawi og wasatiyyaskolen, og al-
Qaradawi var styreformann fra oppstart og fram til våren 20ıo. Wasatiyya har som mål å forene fleksible moderne løsninger med islamsk tenkning. 5

Nettopp denne ideologiske forankringen ble gjenstand for konflikt under den såkalte «Islam Online-krisen» våren 2oıo. Ifølge mine informanter ved IOL Kairo, oppsto uenigheten ved at et nyinnsatt styre i Doha ønsket å gjennomføre store endringer hva gjaldt ideologisk profil og fokusområder, samt flytte hele produksjonen til Qatar. Den mest utbredte oppfatningen mens konflikten utspilte seg, var at det nye styret var uttilfreds med nettstedets wasatiyya-profil og at det i stedet ønsket å dreie IOL i en mer salafistisk eller konservativ retning. ${ }^{6}$ I denne forklaringsmodellen ble veiledningstjenestene især utpekt som problematiske for det nye styret, og både spørsmål og svar stemplet som «uislamske» og «for liberale».? Årsakene til krisen og forklaringsmodellene er mangfoldige og sammensatte, og vil ikke kunne belyses i dybden her. ${ }^{8}$ Men det er verdt å merke seg at krisen kuliminerte i at IOLs kontorer i Kairo, med 350 ansatte, brått ble lagt ned og at al-Qaradawi ble avskjediget som styreformann. Produksjonen av IOL ble flyttet til Doha, og de tidligere ansatte i Kairo lanserte i august 2oro et nytt islamsk nettsted, On Islam, for å videreføre sitt virke.

Denne artikkelen fokuserer på ekteskapsveiledningstjenester på IOLs arabiske samfunnssider (al-safha al-igtima'iya), ${ }^{9}$ og har to formål: For det første, å gi en oversikt over IOLs ekteskapsveiledningstjenester i tiåret forut for krisen, basert på onlineforskning og feltarbeid. Det er gjort mye forskning på IOLs fatwatjenester, ${ }^{\mathrm{IO}}$ men lite om de andre veiledningstjenestene. I så 
måte vil artikkelen bidra til ny kunnskap om et uutforsket emne. For det andre, å utforske hvorvidt endringene som er foretatt på IOLs ekteskapsveiledningstjenester siden IOL-krisen kan sies å gjenspeile en konservativ eller salafistisk dreining, i tråd med mine informanters antakelser.

\section{Forskningsdesign}

Fremstillingen og analysen som presenteres her bygger på over to års nettbasert forsking $^{\text {II }}$ og antropologisk feltarbeid. I perioden desember 2009 til juni 2010, gjennomførte jeg feltarbeid hos samfunnsredaksjonen som blant annet hadde ansvar for ekteskapsveiledningstjenestene. Under feltarbeidet observerte jeg jevnlig redaksjonsmøter og hver enkelt medarbeiders vanlige arbeidsoppgaver, i tillegg til å utføre intervjuer med samfunnsredaksjonen og ekteskapsveiledere. På denne måten fikk jeg innsikt i hvilke avgjørelser som ligger bak det som blir publisert på nettsiden, det Krüger $^{\text {12 }}$ kaller «usynlig kunnskap». Et

\section{IOLs ekteskapsveiledning bunnet $i$ et ønske om å bidra til lange og lykkelige ekteskap.}

eksempel på slik usynlig kunnskap er at jeg fikk anledning til å følge den interaktive veiledningsprosessen fra begynnelse til slutt, det vil si, fra et spørsmål kom inn fra en bruker til det ble lagt ut på nettsiden.

\section{Veiledningstjenestene før krisen}

Ekteskapsveilednings-tjenesten skilte seg fra fatwa-tjenesten på to viktige måter. For det første var spørsmålene fra brukerne som regel ikke av eksplisitt religiøs karakter, men dreide seg i stedet om hverdagsproblemer i ekteskapet. For det andre, i motsetning til fatwatjenesten der respondentene var religiøst skolerte, var de som besvarte veiledningstjenestene profesjonelle veiledere og terapeuter. Ifølge Gräf ${ }^{13}$ var IOL helt fra begynnelsen tenkt som en brobygger mellom sekulær vitenskap og islam, og man trakk derfor på eksperter fra ulike disipliner. IOLs veiledningstjenester skapte et rom der brukere kunne søke veiledning om alle slags hverdagsproblemer, også sensitive spørsmål om for eksempel seksuelle relasjoner. ${ }^{\mathrm{I4}}$ IOL utviklet sine veiledningstjenester i over et tiår, fra I997 fram til våren 20I0. ${ }^{15}$

\section{INTERAKTIVE VEILEDNINGSTJENESTER}

IOL tilbød to typer interaktive veiledningstjenester som tok for seg brukeres ekteskapsrelaterte problemer. Den ene tjenesten het mashakil wa hulul, hvilket kan oversettes med «problemer og løsninger». Den andre het hiwar hayy som kan oversettes med «levende samtale». Mashakil wa hulul var en asynkron tjeneste i den forstand at brukeren sendte inn et spørsmål og mottok svar innen to uker. Brukere fylte ut et nettbasert skjema når de sendte inn sine spørsmål. Skjemaet etterspurte brukerens alder, kjønn, ekteskapelig status, hvor lenge man eventuelt hadde vært gift, bosted og utdanning. Det var ikke nødvendig å fylle ut navn. I tillegg var det et åpent felt hvor brukeren kunne beskrive sitt problem i detalj. Det fantes ingen restriksjoner på antall tegn når det gjaldt beskrivelse av problemet. Under feltarbeid ble jeg fortalt at for noen kan det å skrive langt og inngående om et problem, i seg selv være legende. Samfunnsredaksjonen og veilederne 
ønsket ikke å sette en demper på den type selvberging. ${ }^{\mathrm{i}}$

Mashakil wa hulul var en tjeneste som åpnet opp for komplekse veiledningsspørsmål og dybdesvar. Dette var muliggjort av to faktorer: For det første at det var ubegrenset plass for brukeren til å beskrive sitt problem. For det andre ga den asynkrone tjenesten veiledere mer tid til å reflektere rundt problemet og svare mer i dybden. Spørsmålene rettet til mashakil wa hulul omhandlet for det meste enten ekteskap eller førekteskapelige relasjoner (som regel forlovelse), ${ }^{17}$ og IOL svarte på omtrent ti slike spørsmål i uka. Tjenesten var meget populær blant brukere. Alle spørsmål og svar ble publisert på nettsiden, med unntak av spesielt sensitive problem, eller dersom brukeren spesifikt ba om et privat svar. ${ }^{18}$

Hiwar hayy var den andre interaktive veiledningstjenesten. Denne tjenesten var synkron, i den forstand at spørsmål og svar var umiddelbare. Dialogen ble annonsert på IOLs sider god tid i forveien, sammen med navnet på veilederen og veiledningstemaet. Slike dialoger varte i inntil to timer, og veilederen kunne svare på inntil tretti spørsmål fra brukere hver gang. Spørsmålene og svarene i hiwar hayy var mindre komplekse enn i mashakil wa hulul, og både veiledere og brukere ble oppfordret til å fatte seg i korthet. ${ }^{19}$

\section{INFORMATIVE VEILEDNINGSTJENESTER}

IOL tilbød også sine brukere en ikke-interaktiv, informativ veiledningstjeneste. Denne bestod av essayer som bygget på veilednings-metodikk, og ble kalt «protokoller» av samfunnsredaksjonen. Protokollene tok for seg ulike utbredte ekteskapsproblemer og mulige løsninger på disse. De hadde ofte titler som «hvordan takle pro- blemet x» eller «Ti måter å håndtere x». Protokollene fulgte en nokså standardisert mal. De var ofte skrevet på et enkelt språk og var målrettede og konsise i sin form. En typisk protokoll startet med en kortfattet introduksjon av temaet, for så å belyse ulike praktiske aspekter, og både brukere og veiledere ble ofte sitert om deres syn, erfaring, refleksjoner og råd i slike situasjoner. Som regel ble protokoller avsluttet med en liste over praktiske tips brukeren kunne følge for å få bukt med problemet. Problemene som ble tematisert i protokoller gjenspeilte i stor grad problemer som IOL-brukere sendte inn til de interaktive tjenestene. $^{20}$

\section{SAMFUNNSREDAKSJONENS OPPGAVER}

Samfunnsredaksjonen ${ }^{21}$ hadde produksjonsansvar for ekteskapsveiledningstjenesten. Dens oppgaver innbefattet både skriveog redigeringsarbeid. I så måte hadde samfunnsredaksjonen autoritet til å velge både hvilke temaer det skulle skrives om, og hvordan temaene skulle vinkles. Redaksjonen valgte ut ekteskapsproblemer basert på temaene som IOL-brukerne ofte skrev til veilednings-tjenestene om. Men de fokuserte også på tilleggstemaer som de syntes var viktige. ${ }^{22}$ En rekke av protokollene ble forfattet av samfunnsredaksjonen selv. Andre protokoller ble skrevet av enten frittstående skribenter eller IOL-veiledere. I siste tilfelle var det redaksjonsmedlemmene som redigerte tekstene slik at de passet inn i protokollmalen.

Det tilfalt også samfunnsredaksjonens oppgaver å lese igjennom problemene som brukerne sendte til mashakil wa hulul, og å velge ut den mest egnede veilederen basert på den oppgitte problemstillingen. Valg av veileder var basert på kjennskap til veiled- 
eres formelle kompetanse og praktiske ferdigheter, kjent gjennom tidligere responser på liknende spørsmål. I noen tilfeller sendte redaksjonsmedlemmene komplekse spørsmål til to forskjellige veiledere for å få komplementære tilbakemeldinger. Redaksjonen var også ansvarlig for redigeringen av brukeres spørsmål og veilederes svar. Redigeringen av brukeres spørsmål bestod kun av språkvask, mens redigeringen av veilederes svar kunne til tider være mer omfattende. Samfunnsredaksjonen var også de som valgte hvilke tidligere veiledningssekvenser som skulle lenkes opp til brukerens nåværende spørsmål. Dette ble sett på som et bidrag i å gi brukerne et bredere perspektiv med tanke på egen problemstilling. ${ }^{23}$ Redaksjonsmedlemmene sørget også for at veilederen overholdt tidsfristen for svar. I sum hadde samfunnsredaksjonen mye innflytelse. ${ }^{24}$ Dette er i tråd med Gräfs observasjoner ved fatwa-enheten. ${ }^{25}$

\section{VEILEDNINGENS FORMÅL OG TEMAER}

IOLs ekteskapsveiledning bunnet i et ønske om å bidra til lange og lykkelige ekteskap. Derfor ble det lagt vekt på hvordan jobbe seg gjennom problemer i ekteskapet. Likevel anså veilederne skilsmisse som en utvei dersom problemene var av alvorlig og «uhelbredlig» karakter. ${ }^{26}$ Det mest interessante trekket ved IOLs veiledning var at det utgjorde en blanding av vestlig veiledningsteori fra felt som psykologi og sosialt arbeid, men med et islamsk tilsnitt. Bunt karakteriser dette som «konvensjonell veiledning blandet med islamsk etos». ${ }^{27} \mathrm{I}$ et annet arbeid argumenter jeg for at IOLs ekteskapsveiledning i protokoller konstruerte «the IOL counselling brand $»^{28}-$ IOLs veiledningsvaremerke - og kan sies å bygge på vestlig veiledningsmetodikk innen den humanistiske tradisjonen ${ }^{29}$ der formålet er å stimulere brukeren til å finne fram til egnet løsning på problemet, snarere enn å servere et fiks ferdig svar. Dette gjenspeiles i IOLs veiledning, der veiledere tenderte mot å stimulere brukeren til å reflektere over mulige løsninger på sitt problem, framfor å bidra med fasitsvar. I så måte hadde IOL-veiledningen som mål å bidra til brukerens empowerment og selvaktualisering. Det vil si at veilederen så på den individuelle brukeren og hva hun eller han kunne gjøre for å bedre sin situasjon, altså endringer som var innenfor brukerens egen påvirkningssfære. Med andre ord var veilederne ofte tydelige på at brukeren kunne endre eget handlingsmønster, $i$ håp om at dette resulterte $i$ endret og positiv respons fra ektefellen, men det sistnevnte var slettes ikke garantert.

Veiledningen var på denne måten fokusert på individet, men i en familiesammenheng og innenfor et islamsk rammeverk. I min analyse la veiledningssvarene ofte vekt på hvordan skape dialog med partneren om problemer i ekteskapet. Det ble gitt tips om hvordan sette av både tid og sted til ventileringssamtaler, hvordan uttrykke seg om sin egen opplevelse og unngå klandrende utsagn. I veilederes forslag til mulige løsninger og konkrete tips om hvordan forbedre situasjonen, ble det islamske tilsnittet av veiledningen synliggjort enten i form av referanser til tro, profeten eller til konkrete Koran- eller hadithtekster. ${ }^{30}$ Andre ganger var det islamske tilsnittet implisitt gjennom at veiledningen var godt innenfor en islamsk etisk kodeks. Dersom en ugift kvinne skrev til veilederen at hun hadde hatt samleie med en mann, for eksempel, ville veiledningen dreie i ret- 


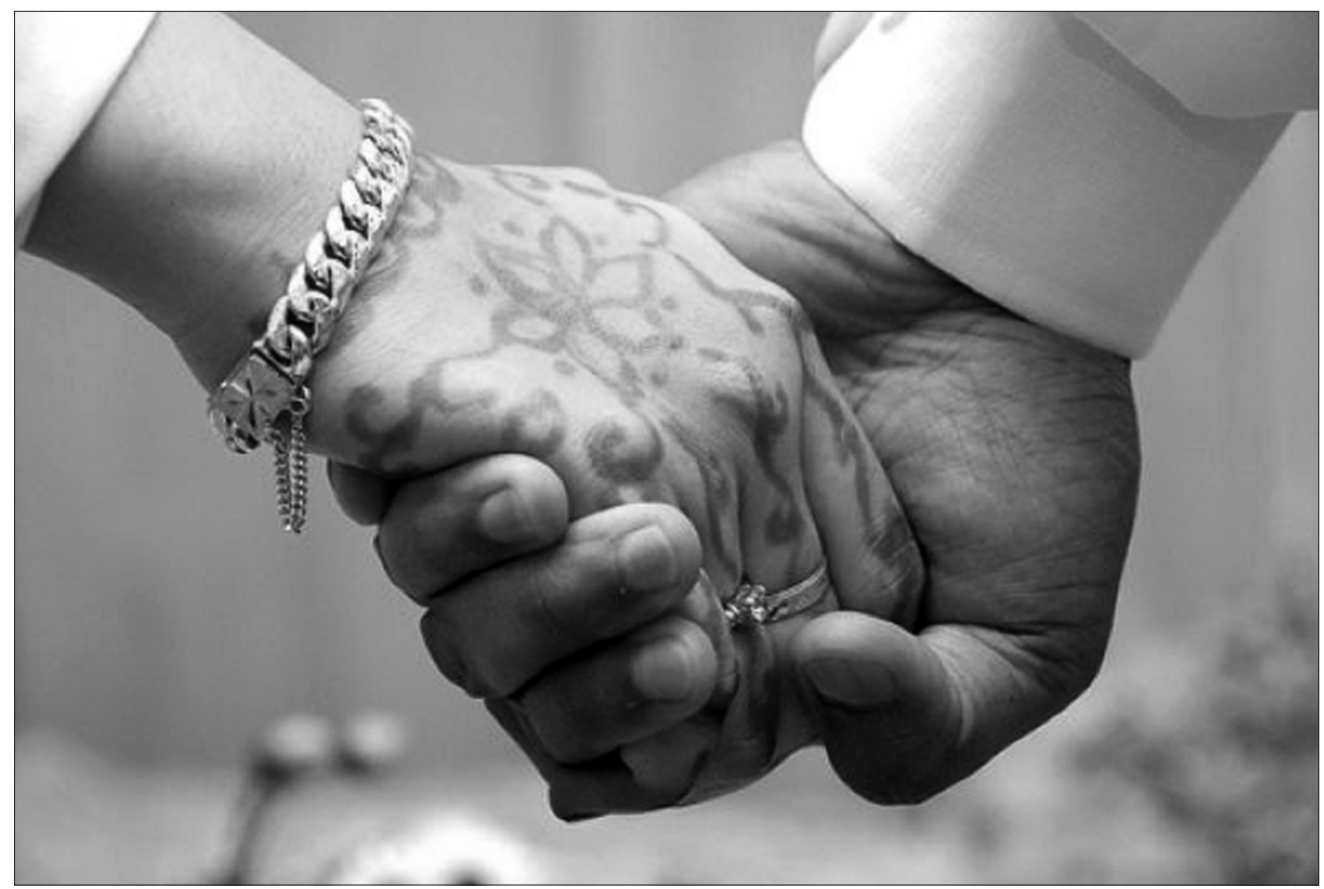

Islam Onlines veiledningssvar la ofte vekt på hvordan skape dialog med partneren om problemer i ekteskapet.

ning av enten å avslutte dette forholdet, eller å legitimere relasjonen gjennom ekteskapsinngåelse.

Brukere skrev inn til de interaktive ekteskapsveiledningstjenestene om blant annet flørt, romantikk, nærhet, seksuelle relasjoner, uenigheter, sinne, krangling, relasjon til svigerforeldre og kommunikasjon. IOL veiledet i hvordan holde flørt og romantikk levende i ekteskapet. Brukere ble gitt råd om hvordan bekjempe mangel på kommunikasjon, hvordan formidle misnøye uten sinne og hvordan forbedre kommunikasjonen generelt. ${ }^{3 \mathrm{I}}$ IOL ønsket også sensitive og tabubelagte temaer velkommen. Seksuelle relasjoner er et eksempel på et sensitivt tema som ble diskutert. IOL hadde som mål å forbedre kunnskap om seksuelle forhold, slik at brukere kunne bli opplyst, og på sikt nyte denne relasjonen innen ekteskapet. Blant tabuområder var spørsmål relatert til onani og homofili.
IOLs standpunkt i forbindelse med henvendelser om homofili var å anbefale måter å kvitte seg med homoseksuell adferd på. Når det gjelder onani ble det skilt mellom onani blant gifte og ugifte. Onani blant gifte var ansett som uønsket adferd som måtte avverges. Onani blant ugifte var forstått som en konsekvens av å ikke være gift. ${ }^{32}$ Innholdet på IOLs sider har blitt beskrevet som en «hybrid mellom reformorientert og konservativ islam».33 Denne beskrivelsen samsvarer med min analyse av ekteskapsveiledningstjenestene. På temaer knyttet til seksualitet fremsto IOL som reformvillige i den forstand at de ønsket større åpenhet om seksuelle relasjoner og ønsket å bidra til folkeopplysning om dette emnet. Videre fremstår IOLs perspektiv på onani blant ugifte som fleksibelt i den forstand at det tar hensyn til realiteten i arabiske samfunn, der mange ikke har råd til å gifte seg. ${ }^{34}$ Det at onani tillates for 
ugifte kan også forstås som et forsøk på å minske risikoen for at det oppstår seksuelle relasjoner utenfor ekteskap. Selv om IOL skriver veldig åpent om homofili, er innholdet i min analyse konservativt eller tradisjonelt, i den forstand at homofili anses som en avvikende adferd som bør «korrigeres» eller «helbredes».35

\section{VEILEDERES ROLLE}

Veiledere som responderte til brukere gjennom hiwar hayy og mashakil wa hulul var som regel utdannete veiledere innen psykologi, sosialt arbeid eller psykiatri. ${ }^{36} \mathrm{De}$ fleste veiledere hadde doktorgrader på sine felt, men et fåtall hadde enten mastergrad eller bachelorgrad. I all hovedsak praktiserte de veiledning offline også. Samtlige veiledere var kurset internt i IOL i det å respondere som nettbasert veileder. Kursingen ga en kompetanse i hvordan tilnærme seg skriftlig basert veileding. Uten kroppsspråk å gå etter, var det andre ting veilederne måtte være på utkikk etter for å få nyanser i bildet som ble tegnet av brukeren. Veilederne var trent i tekstanalyse, som for eksempel hvordan «lese mellom linjene», og hvordan søke etter repetisjoner, nøkkelfraser eller aspekter som brukeren kan ha utelatt. En annen utbredt teknikk var at veilederen forsøkte å forestille seg situasjonen fra perspektivet til en annen part i situasjonen. I tillegg var veilederne trent $\mathrm{i}$ å lete fram det generelle som kunne være av relevans for andre brukere $\mathrm{i}$ de spesifikke problemstillingene. ${ }^{37}$ IOL-veiledere foreslo terapi dersom de oppfattet problematikken som akutt eller meget alvorlig. Veiledere hadde jevnlige veiledningsmøter offline, der spesielt komplekse eller utfordrende problemstillinger ble diskutert. Dette resulterte til tider i at to eller tre veiledere gikk sammen om å forfatte hvert sitt ulike svar. Slike svar ble enten publisert som en samlet respons signert av «IOLs veiledningsteam», eller inneholdt ulike delsvar signert av hver enkelt veileder..$^{8}$

IOLs veiledere hadde ulike veiledningsstiler. Noen var kjent for sin brutale ærlighet. Slike svar kunne bære preg av en frisk tone og inneholde setninger som «våkn opp, det du beskriver er helt hinsides».39 Andre veiledere var kjent for sine utpregede empatiske svar. Disse veilederne vektla å skape en allianse med brukeren ved å utrykke forståelse for at problemet opplevdes som vanskelig. Her ble brukerens

\section{Et vanlig problem blant brukerne var oppdagelsen av negative trekk ved ektefellen etter ekteskapsinngåelsen.}

problem behandlet med silkehansker. Enkelte veiledere var kjent for sin strenghet og religiøs konservatisme. I intervjuer fremstod veilederne som meget bevisste deres veiledningsstil og hvordan dette kunne oppfattes av brukerne. $4^{\circ}$ I mine observasjoner finnes det andre stilistiske forskjeller i veiledernes svar som kanskje veilederne var noe mindre bevisst. For eksempel fremstod noen veiledere som flinkere enn andre til å ikke foreslå «løsninger» (hulul). Det var også forskjeller i hvor fremtredende religiøse referanser var i responsene. Noen svar inneholdt mange eksplisitte referanser til tro og religiøse skrifter, eller til profetens eksempel. Andre svar inneholdt ingen slike referanser og kunne således ha vært publisert på et sekulært veiledningsnettsted. Noen 
responser befant seg også et sted midt i mellom. ${ }^{4}$ Disse forskjellene gjenspeiler antakelig både individuelle ulikheter blant veiledere, og det faktum at veiledere tilpasser svaret til brukerens problemformulering.

\section{BRUKERES MEDVIRKNING}

Hovedandelen av veiledningstjenestenes brukere var kvinner. ${ }^{42}$ Den typiske IOLbrukeren var en ung, gift kvinne med høyere utdannelse. ${ }^{43}$ Det å sende et spørsmål til veiledning kan anses som et forsøk på å løse ens problem, eller en mestringsstrategi. ${ }^{44}$ Mange brukere var aktive også etter at spørsmålet deres hadde blitt besvart. Noen skrev inn for å uttrykke enten misnøye eller tilfredshet med svaret de hadde mottatt fra veilederen. Slike evalueringer la de ut i kommentarfeltene ved sin veiledningssekvens. Noen brukere klaget og krevde at spørsmålet deres skulle sendes til en ny veileder. Et økende antall brukere uttrykte et eksplisitt ønske om at deres problem skulle sendes til en spesifikk veileder. ${ }^{45}$ Slike ønsker ble imøtekommet av samfunnsredaksjonen. Enkelte ganger var formålet kun å gi en positiv tilbakemelding på at veiledningen hadde gitt resultat. Andre ganger ble det dannet en slags veiledningsserie, der brukeren ba om mer veiledning ettersom situasjonen utviklet seg. I tillegg var det mange brukere som kommenterte på andre brukeres veiledningssekvenser.

\section{VANLIGE SPØRSMÅL OG SVAR}

Et vanlig problem blant brukerne var oppdagelsen av ett eller flere negative trekk ved ektefellen etter ekteskapsinngåelsen, som for eksempel at vedkommende var gjerrig, sjalu, sta, kontrollerende, usympatisk eller ikke-religiøs. Brukere ble da veiledet i hvordan vurdere alvorlighetsgraden av dette karaktertrekket, og hvordan å håndtere det. ${ }^{46}$ Det er interessant å merke seg at veiledere ofte uttrykte skepsis til sterk kjønnssegregering og tradisjonell ekteskapsinngåelse (gawaz al-salunat). ${ }^{47}$ Disse tradisjonene ble kritisert for ikke å gi de forlovede tilstrekkelig mulighet til å bli kjent før ekteskapsinngåelse. Denne kritikken bunner til dels $\mathrm{i}$ at IOL-veiledere antar at mange av ekteskapsproblemene i arabiske samfunn skyldes feil valg av ektefelle..$^{8}$

En rekke IOL-brukere skrev om kommunikasjonsproblemer mellom ektefellene. Det kunne dreie seg om både mangel på kommunikasjon og dårlig kommunikasjon. Mer konkret dreide mange spørsmål seg om hvordan få ektefellen i tale, eller hvordan takle sinne, frustrasjon, misnøye, masing eller krangling. Veilederne svarte ofte med konkrete praktiske råd om hvordan stimulere til samtaler og endre kommunikasjonsmønstre. De veiledet også i hvordan øve seg på å uttrykke misnøye på konstruktive måter og hvordan fremstå som mindre anklagende overfor den andre. ${ }^{49}$

Et annet tema brukere ofte skrev til IOL om, var seksuelle relasjoner. En del av spørsmålene kan anses som informasjonssøking. Brukere spurte om tekniske aspekter ved det seksuelle forholdet, som forspill og stillinger. Veiledere ga som regel noen konkrete råd i sine svar, men henviste også til IOL-protokoller om seksuelle relasjoner, og til andre aktuelle informasjonskilder, inkludert Kama Sutra..$^{\circ}$ Dette er informasjon som brukere strengt tatt kunne fått et annet sted, men det kan virke som IOL med sitt islamske stempel fremstod som et halal - et religiøst tillatt - sted å skaffe seg 
informasjon om seksuelle relasjoner fra. Et annet vanlig spørsmål rundt seksuelle relasjoner var relatert til den ene ektefellens manglende entusiasme og til tider frykt for samleie. Dette gjaldt i særlig grad kvinner, og spørsmålene kom både fra kvinnene selv men også fra ektemenn. Veiledere kontekstualiserte sine svar på slike spørsmål. De argumenterte for at kombinasjonen av begrenset sosialisering med personer av det motsatte kjønn, manglende seksualundervisning og det å være oppdratt til at sex er skamfullt, til sammen skaper et uheldig utgangspunkt. Veiledere skisserte mulige fremgangsmåter for hvordan denne type problemer gradvis kunne bedres. Andre vanlige ekteskapsproblemer som IOL-brukeres tok opp, var utroskap, mannens ønske om å ta en kone nummer to, relasjonen til svigerforeldre og ufruktbarhet.

\section{KJØNNSPERSPEKTIVET I IOLS VEILEDNING}

Ved første øyekast kan IOLs interaktive veiledning synes å reprodusere tradisjonelle kjønnsrollemønstre. Særlig fordi det er en overvekt av kvinner som sender inn spørsmål. En kvinne som skrev at hun hadde et problem knyttet til sin ektefelles dårlig humør ble ofte besvart med måter hun kunne takle, og bidra til å nedtone, ektefellens humørsvingninger. Den høye forekomsten av slike svar kan tolkes som om at det å bedre ekteskapsrelasjonen kun hviler på kvinnenes skuldre, og at det dermed er kvinners rolle å sørge for harmoni i ekteskapet. Imidlertid kan dette gi et misvisende bilde. For dersom en mann skrev til IOL om sin aggressive kone, inneholdt veiledningssvaret et liknende fokus på hva han kunne gjøre for å tone ned hennes aggresjonsanfall. Dette er en viktig observasjon, fordi det sier noe om hvordan IOLs veiledning var individfokusert..$^{51}$ På mange måter kan IOLs veilednings-tjenester sees som en del av en global tendens, det Hoover $^{22}$ kaller «terapeutisk kultur», som fokuserer på individet og selvutvikling. Ifølge Hoover karakteriseres dagens samfunn i økende grad av at individer er «søkende» og av at individer søker å forbedre seg selv og sine liv gjennom veiledning. Den enorme veksten i selvhjelpsbøker og veiledningsnettsteder kan sees som en del av denne samfunnsutviklingen. ${ }^{53}$ IOLs veiledningstjeneste utgjør således en del av «tilbudet», gjennom å tilby individbasert veiledning som stimulerer til refleksjon over egne valg og eget liv. Ifølge Hoover kan søken etter et bedre «selv» være både av religiøs og av terapeutisk karakter. Det interessante med IOLs veiledning og det jeg har kalt «IOLs counselling brand» er at her forenes religiøs og terapeutisk tilnærming til individet. IOL før krisen kan derfor sies å ha tilbudt sine brukere religio-terapeutisk veiledning. ${ }^{54}$

\section{IOL i overgangsfasen}

I slutten av mars 2010 fantes det ingen informasjon på IOLs nettside om at de var midt i en krise. IOLs sosiale sider var i stor grad uendret hva gjaldt innhold og layout. Imidlertid var det foretatt et par endringer som er verdt å bemerke. Forfatterens lagrede nettsider fra den 24. mars 2010 avslører at de interaktive veilednings-tjenestene var blitt fjernet fra nettsiden. Verken ikonet hiwar hayy, eller mashakil wa hulul, var å oppdrive, og alle tidligere interaktive veiledningssesjoner var blitt fjernet. Isolert sett kan fjerning av de interaktive veilednings-tjenestene anses som belegg for at det nye styret i Qatar var misfornøyde med 
IOL Kairos veiledningstjenester som ble ansett som «for liberale». I så måte kan fjerningen av de interaktive veiledningstjenestene være et tegn på at IOL-sidene skulle endres $\mathrm{i}$ en konservativ retning. Imidlertid kompliseres bildet av at alle protokollene som bygger på veiledningsmetodikk ikke var fjernet. Hele listen av protokoller bestod i samme form som før krisen, også protokoller om kontroversielle eller sensitive tema som seksuelle relasjoner. Ingen nye protokoller var lagt til av den nye Doha-baserte redaksjonen. Det at protokoller som omhandlet sensitive temaer ikke ble fjernet er forunderlig dersom

\section{mom}

På temaer knyttet til seksualitet fremsto IOL som reformvillige i den forstand at de ønsket større åpenhet.

målet var å føre en strengere islamsk linje. I mai 20I0 inneholdt IOLs sosiale sider poster og layout av mye eldre dato. Innholdet pekte fremdeles ikke i en tydelig retning. Mens krisen pågikk, og helt fram til august 20I0, fremsto IOL-nettsiden først og fremst som ufullstendig. Forfatterens observasjoner av IOL-nettsiden i overgangsfasen tyder enten på at det ikke var det nye IOL-styrets mål å dreie IOL i en konservativ retning, eller på at en slik prosess ennå ikke var fullført.

\section{IOL i ny drakt}

Fra og med august 2010 har IOL fått en helt ny nettside hva gjelder innhold, kategoriseringer og layout. De sosiale nettsidene tilbyr nå nytt innhold som tilsynelatende dreier seg om liknende temaer som
IOL tok for opp før krisen, men populariteten blant brukerne har dalt kraftig. ${ }^{55}$ Alle poster produsert av den tidligere samfunnsredaksjonen i Kairo er nå blitt fjernet. Når det gjelder de ikke-interaktive veiledningstjenestene, det vil si protokoller, finnes disse fortsatt, selv om aktiviteten synes mye lavere enn forut for krisen. I skrivende stund finnes det kun én protokoll som dreier seg om ekteskapelige relasjoner. Denne omhandler hvordan en kone kan håndtere ektefellens humørsvingninger. Både skrivestilen, innhold og oppbygning av denne protokollen minner til dels om protokoller på IOL forut for krisen. Den største forskjellen før og etter krisen når det gjelder de ikke-interaktive veiledningstjenestene synes dermed å dreie seg mer om aktivitetsnivå enn om innhold.

IOLs interaktive veiledningstjenester synes også å være mindre omfattende på den nye nettsiden. For eksempel finnes ikke den synkrone tjenesten hiwar hayy lenger, ei heller en liknende tjeneste under et nytt navn. Derimot tilbyr IOL et asynkront veiledningstilbud under navnet «sosial veiledning» (istisharat igtima'iya). Det at IOL nå tilbyr interaktiv veiledning er i seg selv interessant, ettersom alle spor av interaktiv veiledning ble slettet fra IOLs side i overgangsfasen. Imidlertid inneholder IOLs «sosial veiledning» kun tre veiledningsposter i perioden august 2010 til januar 20II. To av postene dreier seg om ekteskapelige problemer. Begge disse omhandler kommunikasjon mellom ektefellene under ramadan. Det er tankevekkende at disse to postene dreier seg om et emne som trolig ikke vil være relevant for noen IOL-brukere før neste ramadan. Det at det er så få veiledningsposter tyder også på at IOLs nye veiledningstjeneste er rela- 
tivt udynamisk og inaktiv sammenliknet med den forut for krisen.

Innholdet i responsen på det ene spørsmålet minner til dels om «The IOL brand» i den forstand at svaret retter seg mot problemet på et praktisk nivå..$^{6}$ Samtidig er svaret annerledes fra typiske veiledende svar før IOL-krisen fordi det ikke gis noen konkrete tips om hvordan få til en dialog med ektefellen omkring problemet. Det andre spørsmålet er fra en kvinne som klager over at ektefellen ikke tar hensyn til hennes slitenhet og sykdom, og inviterer slekt til iftar uten å avklare med henne om det passer.57 Veilederens respons på dette spørsmålet skiller seg klart fra IOLs tidligere veiledning på en rekke punkter. Først og fremst tar ikke veilederen tak i brukerens problem i det hele tatt. I stedet skriver veilederen om hvordan takle ramadan, og deler generelle tanker om slitasje knyttet til faste under ramadan. Fokuset $\mathrm{i}$ besvarelsen er på hvordan forstå og praktisk håndtere egne reaksjoner på faste, for eksempel aggresjon eller humørsvingninger, og hvordan opprettholde fromhet. Videre skriver veilederen at faste blir enklere dersom man på det tankemessige planet forsoner seg med at dette er noe man gjør frivillig, i stedet for å fokusere på at det er et pålegg fra Gud. Fokuset er på praktiske tilpassninger for å søke forsoning med Gud både nå og etter døden, og det er rikelig med religiøse referanser. Det tas simpelthen ikke tak i brukerens egentlige problem. Responsen inneholder ingen praktiske råd om hvordan komme i dialog med ektefellen og få han til å forstå hennes opplevelse, ei heller hvordan hun kan håndtere ektefellens adferd. I sum fungerer veilederens respons kun som en praktisk guide til hvordan være from muslim og gjennomføre ramadan, et spørsmål brukeren strengt tatt aldri stilte. Disse observasjonene og analysene indikerer at IOL nå vil bruke veiledningstjenesten på en annen måte enn før krisen. Det er verdt å merke seg at de tidligere IOL Kairo-ansatte viderefører de interaktive tjenestene hiwar hayy og mashakil wa hulul under samme navn på den nye nettsiden On Islam..$^{58}$

\section{Konklusjon}

I denne artikkelen har jeg illustrert hvordan nettsiden Islam Onlines (IOL) ekteskapsveiledning før krisen våren 2010 var praktisk rettet og individbasert. Jeg har argumentert for at veiledningen kan anses som en del av en terapeutisk kultur, og at den var fundert på vestlig veiledningsmetodikk med islamsk tilsnitt. På de nye nettsidene er det er kun tre poster som kan kategoriseries som ekteskapsveiledning. Dette gir et begrenset sammenlikningsgrunnlag. Samtidig peker dette nettopp på en av forskjellene mellom det gamle og det nye IOL, nemlig det at det nye IOLs ekteskapsveiledningstjenester fremstår som mindre omfattende og mer udynamiske enn før krisen. En sammenlikning av innhold viser at endringene ikke er entydige, men gir likevel en smakebit på hvordan det nye IOL vil ta form. Det nye IOL synes i mindre grad å forfekte å forene vestlig veiledningsmetodikk med islamske referanser. Snarere er det tegn til at IOLs interaktive veiledningstjeneste i framtiden vil være mer opptatt av å forkynne religiøst innhold enn å løse den enkelte brukers problem. Det kan også være en indikasjon på at IOL i ny drakt ikke har som mål å tilby religioterapeutisk veiledning. Denne dreiningen signaliserer at det nye IOL-styret kan være motstandere av å basere sine ekteskaps- 
veiledningstjenester på vestlig veiledningsmetodikk. Disse observasjonene kan bety at IOL er i ferd med å dreie i en mer konservativ eller salafistisk retning, og dermed gi medhold $i$ antakelsen om at det nye IOLstyret var misfornøyd med gamle IOL Kairos veilednings-tjeneste. Til tross for at motivene for det nye IOL-styrets endringer av redaksjonelt innhold er uklare, synes resultatene av Doha-overtakelsen å peke i to retninger: I) IOL har gått fra å være en av verdens mest populære og suksessrike religiøse nettsteder til å være mindre betydningsfull; og 2) Brukere som tidligere kunne få praktisk rettet ekteskapsveiledning på IOL, vil nå måtte søke svar et annet sted.

\section{$\cdot f \cdot$}

I Jeg vil takke Naima Mouhleb og Dyveke Hamza for konstruktive tilbakemeldinger på tidligere utkast av denne teksten.

2 Hofheinz, Albrecht: "Arab Internet Use: Popular Trends and Public Impact" i: Sakr, N. (red.) Arab Media and Political Renewal: Community, Legitimacy and Public Life. New York: I.B. Tauris, 2007.

3 Personer i alderen i8-30 år fra Egypt og Saudi-Arabia er de mest aktive brukerne av IOL, ifølge Alexa.com: "IslamOn line.net Site Info" (I8.05.I0). Forfatters arkiv, 20I0 a.

4 Religiøs uttalelse fra islamsk lærd.

5 El-Nawawy, Mohammed \& Khamis, Sahar: Islam dot com: contemporary Islamic discourses in cyberspace. New York: Palgrave-Macmillan, 2009.

6 Mine informanter brukte begrepet «salafi» for å betegne det de oppfattet som bokstavtro og streng fortolkning blant nye medlemmer av IOL-styret.

7 Abdel-Fadil, Mona: "The Islam-Online Crisis: A battle of wasatiyya vs. salafi ideologies?” i CyberOrient, http://www .cyberorient.net/article.do?articleId=6239.

8 For en mer inngående diskusjon av krisen se http://www.cyberorient.net/article.do?articleId=6239.

9 Emisk term, dvs. denne inndelingen av IOLs portal i samfunnssider og andre sider er det mine informanter som opererer med. Det brukes entall «safha» og ikke flertall «safhat», på arabisk. I oversettelse til norsk fremstår det som mer naturlig å bruke flertall, dvs. «(nett)sider».
Io Bogstad, Therese: "Mellom juridisk og religøs diskurs: Argumentasjon om islamsk skilsmisse hos Islamon line.net". Masteroppgave, Universitet i Oslo, 2009; Bunt, Gary: Islam in the digital age: e-jihad, online fatwas and cyber Islamic environments. London: Pluto Press, 2003; Gräf, Bettina: "IslamOnline.net: independent, interactive, popular" i Arab Media and Society, 2008. http://www.arab mediasociety.com/topics/index.php?t_article $=182$ (24.03.II); Sisler, Vit: "The Internet and the Construction of Islamic Knowledge in Europe" i Masaryk University Journal of Law and Technology, vol. I, 2007; Sisler, Vit: "European Courts' Authority Contested? The Case of Marriage and Divorce Fatwas On-Line", i Masaryk University Journal of Law and Technology, Vol 3, 2009.

II Jeg logget og kodet tendenser i IOLs ekteskapsveiledningstjenester. Siden IOL-krisen har mye av materialet som er blitt analysert etter hvert blitt fjernet fra IOLs nettside. Imidlertid finnes (uredigerte) transkripsjoner av de interaktive veiledningstjenestene i bokform. Jeg vil der for referere til bøkene framfor egenarkivert materiale.

I2 Krüger, Oliver: "Discovering the Invisible Internet: Methodological Aspects of Searching Religion on the Internet", i Online - Heidelberg Journal of Religions on the Internet, vol. I, 2005

I3 Gräf, Bettina: "IslamOnline.net: independent, interactive, popular", i Arab Media and Society. 2008, http://www .arabmediasociety.com/topics/index.php?t_article $=\mathrm{I} 82$ (24.03.II).

I4 Bunt, Gary 2003: Islam in the digital age: e-jihad, online fatwas and cyber Islamic environments. London: Pluto Press, 2009.

I5 Intervju med Dr. Amira Badran (IOL veileder), Io.o6.IO.

I6 Feltnotater fra observasjon av arbeidsoppgaver, 06.12.09, 07.02.IO og 21.02.IO.

I7 Islamonline.net: Al-tarbiya al-jinsiyya. Beirut: Arab Scientific Publishers, 2004a; Islamonline.net: Ikhtiyar sharik alhaya. Beirut: Arab Scientific Publishers, 2004b; Islamon line.net: Min Adam l Hawwa: Shakawi al-azwaj. Beirut: Arab Scientific Publishers, 2004c; Islamonline.net: Min Hawwa l-Adam: Shakawi al-zawjat. Beirut: Arab Scientific Publishers, 2004d.

I8 Feltnotater fra observasjon av arbeidsoppgaver, 07.02.I0 og 2I.02.IO.

I9 Feltnotater fra observasjon av arbeidsoppgaver, 06.I2.09 og 2I.02.IO.

20 Observasjonsnotater fra redaksjonsmøter i perioden 06.12.09-13-03.10; Abdel-Fadil, Mona (kommende utgivelse): "Islam Online Guides Spouses towards Marital Bliss: IOL's Counselling Perspectives on Marital Communication", i Larsson, G. \& Hoffmann, T. (red.) Muslims and the Information and Communication Technologies (foreløpig tittel, bokmanus er til vurdering ved forlag og planlegges utgitt i løpet av 20II).

2I Samfunnsredaksjonen telte ni personer, hvorav syv var kvinner, forut for IOL-krisen.

22 Feltnotater fra observasjon av arbeidsoppgaver, 06.I2.09 og 2I.02.IO; observasjonsnotater fra redaksjonsmøter i perioden 06.12.09-I3-03.I0. 
23 Feltnotater fra observasjon av arbeidsoppgaver, 06.I2.09, 07.02.IO og 21.02.IO.

24 For en mer inngående diskusjon om samfunnsredaksjonens rolle og innflytelse, se Abdel-Fadil, Mona "New Modes of Communication: Social Networking, Text Messaging, Skype: Egypt", i Encyclopedia of Women \& Islamic Cultures (EWIC): Brill Online (i trykk, publiseres i løpet av april 2OII).

25 Gräf, Bettina, 2008.

26 Intervju med Dr. Amira Badran (IOL-veileder) Io.o6.Io; intervju med Dr. Naamat Awdallah (IOL-veileder) I3.06.IO; intervju med Dr. Amr Abu Khalil (IOL-veileder) I3.06.IO; intervju med Dr. Mona Al Basili (IOL-veileder) I3.06.Io; intervju med Dr. Ahmad Abdallah (tidligere IOL-veileder) 2I.06.IO; intervju med Dr. Mohammed Al Madhi (IOL-veileder) 23.06.IO; intervju med Dr. Fairuz Omar (IOL-veileder) 27.06.I0; intervju med Samar Abduh (IOL-veileder og samfunnsredaksjonsmedlem) 23.05.10 og 02.06.IO.

27 Bunt, Gary, 2003, s. I48.

28 Abdel-Fadil, Mona (kommende utgivelse): "Islam Online Guides Spouses towards Marital Bliss: IOL's Counselling Perspectives on Marital Communication".

29 Hough, Margreth 2006: Counselling: Skills and Theory. London, Hodder Education, 2006.

30 En hadith er en fortelling som omhandler profeten Mohammeds handlinger, samhandlinger og uttalelser. I likhet med Koranen fremstår hadith som en primærkilde om islam. Samtidig er ikke alle hadither antatt å være "sanne", og både deres fortellerkjede og kontekst kan være gjenstand for teologisk diskusjon.

3 I Islamonline.net: Ikhtiyar sharik al-haya. Beirut: Arab Scientific Publishers, 2004b; Islamonline.net: Min Adam lHawwa: Shakawi al-azwaj. Beirut: Arab Scientific Publishers, 2004c; Islamonline.net: Min Hawwa l-Adam: Shakawi al-zawjat. Beirut: Arab Scientific Publishers, 2004d.

32 Intervju med Dr. Ahmad Abdallah (tidligere IOL-veileder); intervju med Samar Abduh (IOL-veileder og samfunnsredaksjonsmedlem) 23.05.IO og 02.06.IO.

33 El-Nawawy, Mohammed \& Khamis, Sahar, 2009, s. I3.

34 Abdel-Fadil, Mona: "Når penger står på spill: Ekteskapelig lykke og ulykke i Midtøsten”, i Babylon: Tidsskrift om Midtøsten og Nord-Afrika, Vol. I, 2003, s. 94-IoI.

35 Intervju med Samar Abduh (IOL-veileder og samfunnsredaksjonsmedlem) 23.05.I0 og 02.06.I0; intervju med Dr. Mohammed Al Madhi (IOL-veileder).

36 Det var åtte veiledere som ofte svarte på spørsmål knyttet til ekteskap, og disse var jevnt fordelt hva gjelder kjønn.

37 Intervju med Samar Abduh (IOL-veileder og samfunns redaksjonsmedlem) 23.05.I0 og 02.06.I0; Feltnotater fra observasjon av arbeidsoppgaver, 07.02.10.

38 Feltnotater fra observasjon av arbeidsoppgaver, 06.I2.09, 07.02.IO og 21.02.IO.
39 Intervju med Dr. Amr Abu Khalil (IOL-veileder) I3.06.IO.

40 Intervju med Dr. Amira Badran (IOL-veileder) Io.o6.IO; intervju med Dr. Naamat Awdallah (IOL-veileder) I3.06.IO; intervju med Dr. Amr Abu Khalil (IOL-veileder) I3.06.Io; intervju med Dr. Mona Al Basili (IOL-veileder) I3.06.Io; intervju med Dr. Ahmad Abdallah (tidligere IOL-veileder) 2I.06.IO; intervju med Dr. Mohammed Al Madhi (IOL-veileder) 23.06.Io; intervju med Dr. Fairuz Omar (IOL-veileder) 27.06.Io; intervju med Samar Abduh (IOL-veileder og samfunnsredaksjonsmedlem) 23.05.IO og 02.06.IO.

4I Islamonline.net: Al-tarbiya al-jinsiyya. Beirut: Arab Scientific Publishers, 2004a; Islamonline.net: Ikhtipar sharik alhaya. Beirut: Arab Scientific Publishers, 2004b; Islamon line.net: Min Adam l-Hawwa: Shakawi al-azwaj. Beirut: Arab Scientific Publishers, 2004c; Islamonline.net: Min Hawwa l-Adam: Shakawi al-zawjat. Beirut: Arab Scientific Publishers, 2004d.

42 Alexa.com: "IslamOnline.net Site Info". 2010, (I8.05.I0), forfatters arkiv, $2010 \mathrm{a}$.

43 Ibid.

44 Harter, Lynn, Japp, Phyllis. \& Beck, Christina: "Vital Problematics of Narrative Theorizing about Health and Healing”, i Harter, L., Japp, P. \& Beck, C. (red.) Narratives, health, and healing: communication theory, research, and practice, New Jersey: Lawrence Erlbaum, 2005; Murphy, Lawrence J. and Mitchell, Dan L.: "When writing helps to heal: E-mail as therapy" i British Journal of Guidance and Counselling 26: II. I998, http://dx.doi.org/Io.I080 103069889808253835 (O2.0I.II). For en utbrodering av brukerens medvirkning, se forfatterens bidrag til EWIC.

45 Intervju med Dr. Amira Badran (IOL-veileder) Io.o6.Io.

46 Islamonline.net: Min Adam l-Hawwa: Shakawi al-azwaj. Beirut: Arab Scientific Publishers, 2004c; Islamonline .net: Min Hawwa l-Adam: Shakawi al-zawjat. Beirut: Arab Scientific Publishers, 2004d

47 Intervju med Dr. Amira Badran (IOL-veileder) Io.o6.Io; intervju med Dr. Naamat Awdallah (IOL-veileder) I3.06.IO, 23.06.Io; intervju med Dr. Fairuz Omar (IOLveileder) 27.06.Io; intervju med Samar Abduh (IOL-veileder og samfunnsredakasjonsmedlem) 23.05.10 og 02.06.Io. For øvrig er "gawaz al-salunat" egyptisk muntlig dialekt og det er dette uttrykket som ble brukt av de intervjuede.

48 Ibid.

49 Islamonline.net: Min Adam l-Hawwa: Shakawi al-azwaj. Beirut: Arab Scientific Publishers, 2004c; Islamonline .net: Min Hawwa l-Adam: Shakawi al-zawjat. Beirut: Arab Scientific Publishers, 2004d.

50 Islamonline.net: Al-tarbiya al-jinsiyła. Beirut: Arab Scientific Publishers, 2004a.

5I Abdel-Fadil, Mona: "New Modes of Communication: Social Networking, Text Messaging, Skype: Egypt” (i trykk).

52 Hoover, Stewart: Religion in the Media Age. London: Routledge, 2006, s. 53 . 
53 Selv om Hoover fremsetter dette argumentet som globalt, kan det innvendes at det hans argument er USA-sentrisk. Til tross for denne innsigelsen mener jeg at argumentet er overførbart til IOL og gjør nærmere rede for dette i "New Modes of Communication: Social Networking, Text Messaging, Skype: Egypt” (i trykk).

54 Ibid.; Abdel-Fadil, Mona (kommende utgivelse): "Islam Online Guides Spouses towards Marital Bliss: IOL's Counselling Perspectives on Marital Communication".

55 Alexa.com: "Islamonline.net site info". 20II, http://www .alexa.com/siteinfo/islamonline.net (I4.OI.II).

56 Awdallah, Naamat: "Ramadan we al hiwar al rohi bein al zawjeen". 2010, http://www.islamonline.net/ar/IOL Counsel_C/I278406813363/127840672545I/(03.0I.II).

57 Naser, Sahar: "Ihtwaa al maraa lil zowj, mohima shaqa". 20I0, http://www.islamonline.net/ar/IOLYouth_C/I2784 07091597/I278406725244/- (03.0I.II).

58 Onislam.net. 20II, http://www.onislam.net/arabic/pro blems-answers.html (24.03.II). 